\title{
PENGARUH LATIHAN TERPUSAT DAN LATIHAN ACAK TERHADAP HASIL PENGUASAAN TEKNIK DASAR BOLA BASKET
}

\author{
Setiana Wati \\ Penjas fkip unib, e-mail: watisetiana33@gmail.com \\ Tono Sugihartono \\ Universitas Bengkulu \\ Sugiyanto \\ Universitas Bengkulu
}

\begin{abstract}
Abstrak
Penelitian ini bertujuan untuk mengetahui pengaruh antara latihan terpusat dan latihan acak terhadap hasil penguasaan teknik dasar bola basket. Penelitian ini menggunakan metode eksperimen yang dilakukan terhadap dua kelompok, yaitu kelompok eksperimen satu yang di beri perlakuan latihan terpusat dan kelompok eksperimen dua di beri perlakuan latihan acak. Penelitian dilakukan di Klub Basket Poltekkes Kemenkes Bengkulu dengan sampel yang di pilih berdasarkan karakteristik tertentu. Analisis statistik yang di gunakan dalam penelitian ini adalah Uji $\mathrm{t}$ untuk menguji hipotesis bahwa "latihan acak memberikan pengaruh lebih baik dibandingkan dengan latihan terpusat dalam meningkatkan keterampilan teknik dasar bola basket". Uji syarat statistik t telah memenuhi syarat homogen dan data berdistribusi normal berdasarkan perhitungan statistik dan pengujian kriteria uji statistic di dapat hasil bahwa latihan terpusat dan latihan acak memberikan pengaruh terhadap hasil penguasaan teknik dasar bola basket. Hal ini diketahui dari data $t_{\text {hitung }}=-5,11>t_{\text {tabel }}=2,11$ dengan taraf $\alpha=0,05$. Kesimpulan dari penelitian ini dilihat dari hasil uji signifikan perbedaan peningkatan latihan kedua kelompok menunjukkan bahwa latihan acak memberikan pengaruh yang lebih signifikan terhadap hasil penguasaan teknik dasar bola basket.
\end{abstract}

Kata Kunci: Latihan terpusat, Latihan acak, Teknik Dasar Bola Basket.

\begin{abstract}
This study aims to determine the effect of centralized training and random exercise on the results of mastery of basic techniques of basketball. This study used experimental methods conducted on two groups, namely the experimental group one which was given the treatment of centralized exercise and the experimental group of two in the treatment of random treatment. The research was conducted at Club Basket Poltekkes Kemenkes Bengkulu with selected samples based on certain characteristics. The statistical analysis used in this study is $t$ test to test the hypothesis that "randomized exercise gives better effect than centralized training in improving basic basketball technique skills". Test statistic requirement $t$ has complied with homogeneous requirements and normal distributed data based on statistical calculation
\end{abstract}


and statistical test criterion test in can result that centralized exercise and random exercise have an effect on the result of mastery of basic technique of basketball. It is known from thitung = 5,11> ttable $=2,11$ with $\alpha=0,05$. The conclusions of this study seen from the results of significant test differences in the improvement of the two groups showed that the random exercise gives a more significant effect on the results of mastery of basic techniques of basketball.

Keywords: Centralized exercise, Random exercise, Basic Basketball Technique.

\section{PENDAHULUAN}

Keberhasilan dalam proses latihan sangat tergantung dari kualitas latihan yang dilaksanakan, karena proses latihan merupakan perpaduan kegiatan dari berbagai faktor pendukung agar terwujudnya prestasi olahraga tinggi. Salah satu patokan yang sering digunakan untuk menggambarkan kurang meningkatnya prestasi olahraga bola basket di suatu club adalah kurang efektifnya suatu latihan dan latihan cenderung kurang menarik.

Latihan seperti ini dapat menghambat suatu penguasaan teknik dasar yang mana juga akan menghambat peningkatan suatu prestasi atlet. Hasil observasi di suatu klub bola basket Poltekkes Kemenkes Bengkulu menunjukan bahwa anak berlatih tidak sesuai dengan jadwal yang telah di tentukan. Metode latihan pun kurang menarik sehingga anak cenderung merasa bosan. Hal seperti ini membuat latihan tidak terprogram dengan baik dan tidak efektif. Untuk itu di perlukannya metode latihan yang menarik dan tepat dalam rangka usaha untuk meningkatkan penguasaan teknik dasar passing, dribbling dan shooting. Dalam permainan bola basket, banyak variasi latihan yang dapat dilakukan. Salah satunya dalam Mahendra, (2007:208) adalah "pengaturan secara terpusat (blocked practice) dan secara acak (random practice)".

Latihan terpusat yaitu menyelesaikan satu keterampilan terlebih dahulu sebelum berpindah ke keterampilan lainnya. Dengan demikian, anak akan terpusat pada satu keterampilan sebelum berpindah ke keterampilan lain. Sedangkan latihan acak merupakanan latihan yang memberikan kesempatan kepada siswa untuk melakukan berbagai bagian keterampilan dalam waktu bersamaan, tanpa dipisahkan oleh jenis keterampilan, Richard Decaprio ( 2013:135137).

Berdasarkan penjelasan di atas dan berkaitan dengan upaya meningkatkan kemampuan teknik dasar passing, dribbling, dan shooting dalam olahraga bola basket, maka menjadi penting untuk diketahui perbedaan yang ditimbulkan oleh latihan terpusat dan latihan acak. Dalam memberikan kedua cara pengaturan latihan di atas, peneliti menemukan bahwa kondisi anak yang masih dalam tahap latihan belum terungkap dengan jelas. Dilatar belakangi oleh kondisi di lapangan dan harapan untuk adanya perbaikan dalam proses latihan, maka perlu dilakukan penelitian mengenai latihan terpusat dan latihan acak. Hal ini untuk membuktikan keunggulan dari tiap metode latihan tersebut terhadap penguasaan kemampuan teknik dasar passing, dribbling dan shooting permainan bola basket. Berdasarkan latar belakang, identifikasi masalah, dan batasan masalah dapat dirumuskan beberapa permasalahan sebagai berikut : Apakah terdapat perbedaan antara latihan terpusat dan latihan acak terhadap 
hasil penguasaan teknik dasar bola basket?. Latihan manakah antara latihan terpusat dan latihan acak yang memberikan pengaruh lebih signifikan terhadap hasil penguasaan teknik dasar passing, dribbling dan shooting dalam permainan bola basket?.

Latihan adalah kegiatan yang di ulang secara sistematis dalam praktek untuk memperoleh kemahiran yang maksimal, bertujuan untuk membentuk, memelihara dan meningkatkan prestasi dengan keteraturan dan pengulangan, KONI (2012:7). Apta Mylsidayu \& Febi Kurniawan (2015:48) Istilah latihan berasal dari dua kata dalam bahasa inggris yang dapat mengandung beberapa makna seperti : practice, exercises, dan training. Pengertian latihan yang berasal dari kata practice adalah aktivitas untuk meningkatkan keterampilan (kemahiran) berolahraga dengan menggunakan berbagai peralatan sesuai dengan tujuan dan kebutuhan cabang olahraganya. Artinya, selama dalam kegiatan proses berlatih melatih agar dapat menguasai keterampilan gerak cabang olahraganya selalu dibantu dengan menggunakan berbagai peralatan pendukung.

Pengertian latihan yang berasal dari kata exercise adalah perangkat utama dalam proses latihan harian untuk meningkatkan kualitas fungsi sistem organ tubuh manusia sehingga mempermudah atlet dalam penyempurnaan geraknya. Susunan materi latihan dalam satu kali tatap muka berisi : pembukaan/pengantar latihan, pemanasan (warning up), latihan inti, latihan tambahan (suplemen), dan penutup (cooling down).

Pengertian latihan yang berasal dari kata training adalah suatu proses penyempurnaan kemampuan olahraga yang berisikan materi, teori, dan praktik, menggunakan metode dan aturan pelaksanaan dengan pendekatan ilmiah, memakai prinsip-prinsip latihan yang terencana dan teratur, sehingga tujuan latihan dapat tercapai tepat pada waktunya.

Salah satu ciri dari latihan baik yang berasal dari kata practice, exercise, dan training adalah adanya beban latihan. Beban latihan merupakan rangsangan motorik (gerak) yang dapat diatur dan dikontrol oleh pelatih maupun atlet untuk memperbaiki kualitas fungsional berbagai peralatan tubuh.

Usia muda memiliki efisiensi dalam melakukan kegiatan olahraga. Prestasi dan efisiensi yang tinggi dalam melakukan olahraga bukan tergantung pada umur kronologis, akan tetapi lebih banyak ditentukan oleh umur biologis (kematangan) manusia. Potensi fungsional dan kemampuan seseorang untuk beradaptasi terhadap stimulus tertentu lebih penting dari pada umur kronologis, Andi Suhendro, dkk., (2007:33.19). Artinya, latihan yang dilakukan beberapa tahun secara rutin dalam cabang olahraga yang sama, dengan intensitas yang tinggi sesuai dengan potensi atlet, maka tubuh atlet akan dapat menyesuaikan diri sesuai dengan kekhususan dan kebutuhan cabang olahraga tertentu.

Secara teoritis, cara penyampaian materi latihan dengan terpusat pada salah satu tugas gerak tertentu disebut dengan pengaturan latihan terpusat. Cara pengaturan latihan ini dominan digunakan pada pembelajaran atau pelatihan teknik cabang olahraga yang mempunyai keterampilan yang kompleks, salah satunya adalah bola basket.

Mengenai latihan terpusat, Mahendra (2007:281) menyebutkan "pengaturan latihan terpusat dilaksanakan dengan mendahulukan satu tugas hingga selesai sebelum pindah ke tugas lainnya". Richard Decaprio (2013:135) latihan terpusat yaitu menyelesaikan satu keterampilan terlebih dahulu sebelum berpindah ke keterampilan lainnya. Dengan demikian, para siswa akan terpusat pada satu 
keterampilan (satu tugas) sebelum berpindah ke keterampilan (tugas) lain.

Otte dan Zanic (2008) mengemukakan latihan terpusat memfokuskan pada satu aspek teknik, latihan dilakukan secara berulang-ulang sampai teknik dikuasai dengan baik. Wrigh dan Shea (2000) menjelaskan secara rinci peserta latihan menggunakan latihan terpusat menunjukan pencapaian yang tinggi selama latihan. kemudian Bilalovic (2007) menjelaskan latihan semacam itu memberikan waktu kepada siswa untuk berkonsentrasi pada pencapaian dari tiap tugas, sehingga mereka dapat meningkatkan keterampilan yang penting sebelum meneruskan keterampilan yang berikutnya. Dalam pelaksanaannya di lapangan, latihan terpusat diberikan pelatih kepada anak didik dilakukan secara bertahap, yaitu memberikan satu tugas gerak tertentu sampai gerakan tersebut dapat dikuasai dengan baik oleh anak didik. Setelah itu diberikan materi latihan dengan tugas gerak yang lainnya. Untuk contoh, pelatih mengambil keputusan untuk melatih ketiga keterampilan bola basket sekaligus, yaitu passing, dribbling dan shooting.

Materi latihan pertama adalah passing yang dilakukan secara berulang-ulang. Latihan passing diberikan dalam beberapa repetisi dan memberikan koreksi atau perbaikan teknik gerak jika diperlukan. Setelah anak didik melakukan dan menyelesaikan teknik passing sebanyak 50 kali dan telah dirasa cukup, maka berikutnya adalah materi latihan dribbling dengan prosedur latihan yang sama, begitu juga dengan latihan shooting. Maka dalam hal ini terjadi pemusatan pada salah satu teknik gerak.

Mengenai latihan acak, Mahendra (2007:282) menjelaskan: "Latihan acak menghendaki atlet melakukan berbagai kegiatan latihannya dalam satu waktu, tanpa dipisah-pisahkan oleh jenis keterampilannya". Artinya. Dalam satu waktu materi latihan yang diberikan beragam dengan susunan yang acak.

Richard Decaprio (2013:137) latihn secara acak merupakan latihan yang memberikan kesempatan kepada siswa untuk melakukan berbagai bagian keterampilan dalam waktu bersamaan, tanpa dipisahkan oleh jenis keterampilan. Mereka seolah berputar untuk melakukan semua keterampilan dengan cara acak.

Untuk contoh, pada pertemuan pertama diberi latihan passing, dribbling, dan shooting secara selang-seling. Pelatih mengatur latihan dengan meminta atletnya agar melakukan ketiga keterampilan teknik dasar secara sekaligus, setelah atlet melakukan passing satu kali, ia langsung melakukan driibling, kemudian melakukan shooting, lalu kembali ke passing lagi. Setiap keterampilan dilakukan satu kali kemudian langsung pindah ke keterampilan lain, membentuk suatu putaran dalam lingkaran dengan repetisi yang sama dengan latihan terpusat.

Bilalovic (2007) menjelaskan kamu mungkin terkejut jika saya katakan bahwa latihan acak lebih baik dibangdingkan latihan terpusat. Tetapi ini adalah kebenaran, studi penelitian mengidentifikasikan bahwa latihan terpusat menghasilkan pencapaian efektif hanya selama latihan awal, tetapi tidak menciptakan hasil dalam jangka waktu yang lama. Kemudian Lee dan Magill (1985) dalam otte dan Zanic (2008) menjelaskan bahwa latihan acak lebih efisien terutama saat variasi tugas serupa, ke struktur tugas variasi yang sama. Ini secara fungsional mengurasi pemborosan dari satu percobaan ke percobaan lain. Selanjutnya Wilde dan Shea (2000) menjelaskan data menyatakan bahwa latihan acak mengakibatkan peserta mengadopsi suatu struktur tanggapan yang 
seragam. Dalam hal ini pencapaian yang akan diperoleh siswa relative akan sama atau merata.

Senada dengan Bilalovic, Richard Decaprio (2013:138) menjelaskan tidak banyak orang yang menyangka bahwa sebenarnya penerapan latihan acak justru dapat memberikan hasil yang lebih baik dari pada penerapan latihan terpusat. Dalam hal ini, banyak keunggulan yang di miliki oleh latihan secara acak ketimbang latihan secara terpusat. Pertama, dari segi penguasaan gerakan antara latihan secara terpusat dan latihan acak, siswa yang berlatih keterampilan secara acak ternyata lebih unggul dari pada siswa yang berlatih keterampilan secara terpusat. Keterampilan siswa yang diperoleh dari latihan secara acak lebih menonjol dari pada keterampilan siswa yang diperoleh dari latihan keterampilan secara terpusat. Kedua, ketika kemampuan siswa di ukur setelah proses latihan, baik dengan tes acak maupun tes terpusat, keterampilan siswa yang diperoleh dari latihan secara acak ternyata lebih unggul dalam segala hal.

\section{METODE}

Penelitian ini menggunakan metode eksperimen. Sugiyono (2006:20) Eksperimen dapat di artikan sebagian dari metode penelitian yang digunakan untuk mencari pengaruh perlakuan tertentu terhadap yang lain dalam kondisi yang terkendalikan. Penelitian ini bertujuan untuk mengetahui ada tidaknya pengaruh antara variabel bebas terhadap variabel terikat (dependent variables dan independent variables). Variabel yang dimaksud dalam penelitian ini adalah latihan terpusat dan latihan acak (variabel bebas), sedangkan penguasaan teknik dasar (variabel terikat).

Desain yang digunakan dalam penelitian ini adalah Pre-tes Post-Tes Group Design. Desain penelitian menggunakan dua kali pengumpulan data yaitu dengan melakukan pre-test dan post-test. Pengukuran pertama dilakukan melalui tes awal (pre-test) dan pengukuran kedua melalui tes akhir (post-tes). Penetapaan kelompok dilakukan dengan cara matching. Di awali dengan tes awal, orang coba di tes kemudian hasilnya di rangking dari yang terbesar ke yang terkecil. Seluruh anggota yang telah di tes dan di rangking di bagi ke dalam dua kelompok yaitu kelompok A dan kelompok B. Supaya kedua kelompok memiliki hasil yang sama dan homogen maka di bagi dengan cara zig-zag yaitu $A B=B A$. Diharapkan dengan cara itu dapat memberikan hasil yang sama dan setara.

Data yang akan di kumpulkan dalam penelitian menggunakan tes dan pengukuran dalam olahraga. Tes yang digunakan adalah tes memantulkan bola ke tembok, menggiring bola, dan menembak bola ke ring basket selama 1 menit (Ngatman, 2001:10). Dalam pengumpulan data di perlukan alat pengukuran, sehingga dengan menggunakan alat ini akan diperoleh data yang merupakan hasil pengukuran. Andi Suntoda (2009:1) menegaskan bahwa tes adalah suatu alat ukur atau instrumen yang digunakan untuk memperoleh informasi/data tentang seseorang/objek tertentu. Dalam penelitian pengukuran dilakukan dua kali yaitu pada awal dan akhir penelitian atau sebelum dan sesudah treatment diberikan. Jenis instrument yang digunakan untuk mengukur penguasaan keterampilan teknik dasar adalah tes passing (memantulkan bola ke tembok), dribbling (menggiring bola) dan shooting (menembak bola ke ring selama 1 menit). Instrumen pengumpulan data memiliki nilai reliabilitas tes sebesar 0,893 dan nilai validitas 0,804. (Ngatman, 2001:10).

Setelah data terkumpul, langkah selanjutnya adalah mengolah data dan menganalisis data tersebut secara statistik. 
Langkah-langkah yang dilakukan dalam menganalisis data adalah dengan uji prasyarat (normalitas dan homogenitas) dan uji hiopotesis.

\section{HASIL DAN PEMBAHASAN}

\section{Hasil}

Penelitian ini dilakukan di klub basket poltekkes kemenkes Bengkulu. Adapun sampel dalam penelitian ini adalah anggota klub basket yang memilki kriteria tertentu. Dari data yang telah di peroleh sebanyak 40 orang di bagi ke dalam dua kelompok eksperimen yaitu kelompok eksperimen satu di beri latihan terpusat dan kelompok eksperimen dua di beri latihan acak.

Dari hasil pengukuran tes passing, dribbling dan shooting yang dilakukan di klub basket Poltekkes Kemenkes Bengkulu pada tes awal kelompok eksperimen 1 di dapat nilai minimum 50, nilai maksimum 74 , mean (ratarata) 63,5, standar deviasi 5,95. Sedangkan pada kelompok eksperimen 2 didapat nilai minimum 50, nilai maksismum 74 , mean (rata-rata) 63,9, standar deviasi 6,21.

Setelah pemberian latihan terpusat dan latihan acak, dilakukan kembali pengambilan data kedua kelompok. pada tes akhir kelompok eksperimen 1 di dapat nilai minimum 65, nilai maksimum 90, mean (ratarata) 79,5, standar deviasi 6,18. Sedangkan pada kelompok eksperimen 2 didapat nilai minimum 79 , nilai maksimum 98, mean (ratarata) 89,15 , standar deviasi 5,60.

Sebelum melakukan uji hipotesis terlebih dahulu di lakukan uji prasyarat normalitas dan homogenitas. Berdasarkan hasil perhitungan dengan menggunakan ChiKuadrat dapat diketahui bahwa hasil pre test dan post test berdistribusi normal. Hasil uji normalitas pada kelompok eksperimen 1 dan eksperimen 2 disajikan dalam tabel berikut:
Tabel 1. Hasil Uji Normalitas

\begin{tabular}{|c|c|c|c|c|c|}
\hline \multirow[t]{3}{*}{ no } & \multicolumn{2}{|c|}{ Variabel Passing } & $X^{2}$ hitung & $\mathrm{X}^{2}$ tabel & Ket \\
\hline & $\begin{array}{c}\text { Eksperimen } \\
1\end{array}$ & \multirow[t]{2}{*}{$\begin{array}{l}\text { Pre } \\
\text { Test }\end{array}$} & 0,62 & 14,067 & \multirow[t]{2}{*}{ Normal } \\
\hline & $\begin{array}{c}\text { Eksperimen } \\
2\end{array}$ & & 0,56 & 14,067 & \\
\hline \multirow[t]{2}{*}{2.} & $\begin{array}{c}\text { Eksperiman } \\
1 \\
\end{array}$ & \multirow[t]{2}{*}{$\begin{array}{l}\text { Post } \\
\text { Test }\end{array}$} & 0,06 & 12,592 & \multirow[t]{2}{*}{ Normal } \\
\hline & $\begin{array}{c}\text { Eksperimen } \\
2\end{array}$ & & 3,6 & 11,070 & \\
\hline
\end{tabular}

Tabel.1 menunjukan bahwa hasil dari pengujian normalitas pada data tes awal dan tes akhir dengan $n=20$ pada taraf signifikan $\alpha=0,05$ di peroleh $\quad X^{2}$ tabel $=14,067$ yang lebih besar dari $X^{2}$ hitung sehingga dapat disimpulkan skor yang diperoleh dari data tes berdistribusi normal.

Berdasarkan hasil perhitungan menggunakan uji bartlett dapat diketahui bahwa hasil tes awal dan tes akhir passing, dribbling dan shooting homogen. Hal ini terlihat pada tabel berikut:

Tabel 2. Hasil Uji Homogenitas

\begin{tabular}{|c|c|c|c|c|}
\hline No. & Kelompok & $\mathrm{X}^{2}$ hitung & $\mathrm{X}^{2}$ tabel & Ket \\
\hline 1. & Eksperimen 1 & 0,874 & 3,841 & Homogen \\
\hline 2. & Eksperimen 2 & 0,414 & 3,841 & Homogen \\
\hline
\end{tabular}

Dari perhitungan data di atas, hasil $\mathrm{X}^{2}$ hitung tes awal adalah 0,874, dan tes akhir adalah 0,414 sedangkan $\mathrm{X}^{2}$ tabel dengan $\mathrm{dk}$ adalah $\mathrm{k}-1=1$ di dapat $\mathrm{X}^{2}$ tabel adalah 3,841. Ternyata bahwa $X^{2}$ hitung $<X^{2}$ tabel sehingga dapat disimpulkan bahwa varians - varians adalah homogen.

Setelah melakukan uji prasyarat normalitas dan homogenitas, selanjutnya dilakukan uji hipotesis. Untuk menguji hipotesis penelitian digunakan analisis t-test dengan taraf signifikansi 5\%. Rangkuman hasil perhitungan t-test dapat dilihat pada tabel berikut:

Tabel 3. Uji Hipotesis

\begin{tabular}{|c|c|c|c|}
\hline Data & thitung & ttabel & Keterangan \\
\hline Antara Pre Tes & 0,21 & 2,101 & $\begin{array}{c}\text { Non } \\
\text { Signifikan }\end{array}$ \\
\hline $\begin{array}{c}\text { Pre Test \&Post Test } \\
\text { Latiha Terpusat }\end{array}$ & 8,12 & 2,101 & Signifikan \\
\hline $\begin{array}{c}\text { Pre Test \& Post Test } \\
\text { Iatihan Acak }\end{array}$ & 13,50 & 2,101 & Signifikan \\
\hline
\end{tabular}




\section{Pembahasan}

Berdasarkan dari kajian teori serta perhitungan statistik dengan mengacu pada kesimpulan terhadap analisis yang dilakukan. Dalam pembahasan ini akan merujuk pada hipotesis yang diajukan dalam penelitian yaitu apakan terdapat perbedaan yang signifikan antara latihan terpusat dan latihan acak terhadap hasil penguasaan teknik dasar bola basket pada klub basket Poltekkes Kemenkes Bengkulu dan apakah latihan acak memberikan pengaruh yang lebih signifikan dari pada latihan terpusat terhadap hasil penguasaan teknik dasar bola basket pada klub basket Poltekkes Kemenkes Bengkulu.

Untuk mendapatkan prestasi yang baik, maka perlu menguasai dan mengembangkan berbagai keterampilan teknik dasar. Dalam menguasai dan mengembangkan keterampilan dasar perlu dilakukannya latihan. KONI (2012:7) menegaskan bahwa latihan adalah kegiatan yang diulang secara sistematis dalam praktek untuk memperoleh kemahiran yang maksimal, bertujuan untuk membentuk, memelihara dan meningkatkan prestasi dengan keteraturan dan pengulangan. Tugas utama dalam latihan adalah menggali, menyusun, dan mengembangkan konsep berlatih melatih dengan memadukan antara pengalaman praktis dan pendekatan keilmuan, sehingga proses berlatih melatih dapat berlangsung tepat, cepat, efektif, dan efisien. Agar tugas tersebut dapat tercapai sesuai dengan tujuan yang diharapkan maka diperlukannya penyusunan program latihan.
Program latihan yang baik seharusnya berisikan materi teori, materi praktek, metode, dan sasaran latihan yang dirinci pada setiap tahap periodeisasi. Latihan dapat dilakukan dengan beberapa macam latihan seperti menggunakan alat bantu, menggunakan metode latihan terpusat, menggunakan metode latihan acak dan latihan keterampilan tunggal. Dari beberapa macam latihan yang dapat digunakan tersebut diantaranya adalah dengan menggunakan metode latihan terpusat dan metode latihan acak. Richard Decaprio (2013:135) latihan terpusat yaitu menyelesaikan satu keterampilan terlebih dahulu sebelum berpindah ke keterampilan lainnya. Sedangkan latihan acak merupakan latihan yang memberikan kesempatan kepada siswa untuk melakukan berbagai bagian keterampilan dalam waktu bersamaan, tanpa di pisahkan oleh jenis keterampilan. Bilalovic (2007) menjelaskan bahwa latihan acak lebih baik dibandingkan latihan terpusat. Studi penelitian mengidentifikasikan bahwa latihan terpusat menghasilkan pencapaian efektif hanya selama latihan awal, tetapi tidak menciptakan hasil dalam jangka waktu yang lama.

Perhitungan t-test terhadap keterampilan teknik dasar passing, dribbling dan shooting menyatakan bahwa ada perbedaan yang berarti antara latihan terpusat dan latihan acak. Hal ini dapat terlihat pada uji statistik $t$ pada tes akhir dimana $t_{\text {hitung }}=-5,11>t_{\text {tabel }}=2,101$. Sehingga terdapat perbedaan yang sangat signifikan antara kelompok latihan terpusat dan latihan acak. latihan acak memberikan pengaruh yang lebih baik, hal ini dapat dianalisis dari peningkatan antara pre test dan post test masing-masing kelompok eksperimen.

Dari perbedaan pengaruh yang ditimbulkan akibat dari bentuk latihan yang diberikan, dapat diduga bahwa latihan acak 
memungkinkan peningkatan hasil penguasaan teknik dasar yang lebih baik, dibandingkan dengan latihan terpusat. Hal ini dikarenakan dari segi kebermaknaan gerakan latihan acak menampilkan tugas yang berbeda dari pada sebelumnya dan lebih menggugah sistem memori dalam otak, keberbedaan ini akan di anggap lebih bermakna karena selalu merangsang pikiran sebelumnya.

\section{PENUTUP}

\section{Simpulan}

Berdasarkan hasil penelitian yang telah dilaksanakan serta dari data yang telah di hitung melalui uji prasyarat dan uji $t$, bahwa sampel berdistribusi normal dan homogen. Hasil uji $t$ pada penelitian ini diperoleh $t_{\text {hitung }}=-5,11>t_{\text {tabel }}=2,101$ sehingga dapat di simpulkan bahwa latihan terpusat dan latihan acak berpengaruh terhadap hasil penguasaan teknik dasar bola basket pada klub basket Poltekkes Kemenkes Bengkulu. Latihan acak ternyata memberikan pengaruh yang lebih baik dari pada latihan terpusat, hal ini dapat dilihat dari analisis perbedaan peningkatan kedua kelompok.

\section{Saran}

Adapun saran-saran yang dapat di kemukakan sesuai hasil penelitian, pembahasan, dan kesimpulan yang telah di uraikan di atas, maka penelitian ini dapat berguna bagi pelatih bola basket agar dapat menggunakan metode latihan acak dan penyusunan program latihan khususnya dalam melatih keterampilan teknik dasar guna meningkatkan penguasaan teknik dasar bola basket yang lebih baik. Sedangkan bagi atlet agar dapat mengembangkan kemampuan bermain bola basket dalam melakukan keterampilan teknik dasar bola basket melalui metode latihan secara acak.

\section{DAFTAR PUSTAKA}

Abdullah, Arma. (2008). Dasar-Dasar Pendidikan Jasmani. Jakarta: Direktorat Jendral Pendidikan Tinggi, Departemen Pendidikan dan Kebudayaan

Ahmadi, Nuril. (2007). Permainan Bola Basket. Solo: Era Intermedia

Alexon, (2014). Modul Pembelajaran Statistik Pendidikan. Bengkulu:UNIB

Brittenham, Greg. (1998). Petunjuk Lengkap Latihan Pemantapan Bola Basket. Jakarta: PT RajaGrafindo Persada

Decaprio, Richard. (2013). Aplikasi Teori

Pembelajaran Motorik di Sekolah.

Jogjakarta: DIVA Press

Hal, Wissel. (1994). Bola Basket. Jakarta: PT Raja Grafindo Persada

Jon, Oliver. (2003). Dasar-Dasar Bola Basket. Bandung: Pakar Raya

KONI, (2012). Rencana Strategis Komite Olahraga Nasional Indonesia Tahun 20112015. Jakarta: KONI PUSAT

Milsidayu, Apta \& Kurniawan, Febi. (2015). Ilmu Kepelatihan Dasar. Bandung: Alfabeta

Ngatman. (2001). Tes dan Pengukuran. Yogyakarta: Dik-S FIK UNY

Riduwan. (2013). Dasar-dasar Statistika. Bandung : Alfabeta 